Gut, 1982, 23, 553-557

\title{
Effect of highly selective vagotomy on pancreatic exocrine function and on cholecystokinin and gastrin release
}

\author{
N I RAMUS, R C N WILliAMSON*, J M OLIVER, and D JOHNSTON† \\ From the University Department of Surgery, Bristol Royal Infirmary, Bristol
}

SUMmARY The effect of highly selective vagotomy on pancreatic exocrine function and the release of gastrin and cholecystokinin was studied in 10 patients with endoscopically-proven duodenal ulceration. Cholecystokinin and gastrin concentrations in serum both increased significantly after highly selective vagotomy. Amylase concentration in the duodenal aspirate increased significantly after vagotomy, but trypsin concentration remained unchanged. The expected reductions in gastric acid secretion were noted. Thus highly selective vagotomy reduces acid secretion effectively in patients with duodenal ulcer without impairing the exocrine function of the pancreas.

Impairment of pancreatic and hepatobiliary function may help to explain the diarrhoea and steatorrhoea that follow truncal vagotomy and pyloroplasty in $25-40 \%$ of patients. ${ }^{1-8}$ Reduced pancreatic exocrine secretion after truncal vagotomy has been ascribed variously to parasympathetic denervation, ${ }^{910}$ suppressed release of intestinal hormones, ${ }^{11-13}$ altered gastric emptying ${ }^{13-15}$ and, most recently, interference with enteropancreatic reflexes. ${ }^{13}{ }^{16}$ The introduction of highly selective vagotomy for the treatment of duodenal ulceration has greatly reduced the incidence of dumping, diarrhoea, and steatorrhoea, 5681718 probably because postoperative gastric emptying of solid and semi-solid meals is unaffected, ${ }^{15}{ }^{19-20}$ and gastric emptying of fluids is less precipitate than after truncal vagotomy and drainage. ${ }^{1921}$ Highly selective vagotomy might therefore be expected to cause less interference with pancreatic exocrine function than truncal vagotomy. The present study examines this prediction.

\section{Methods}

Ten patients with endoscopically-proven duodenal ulceration, who had given informed consent, were studied shortly before and two to three months after highly selective vagotomy; this was performed by a

\footnotetext{
* Address for correspondence: Professor R C N Williamson, Department of Surgery, Bristol Royal Infirmary, Bristol BS2 8HW.

† Present address: The General Infirmary, Gt George Street, Leeds LS1 3EX. Received for publication 13 November 1981
}

standard technique. ${ }^{22}$ A Lundh test meal $\ddagger$ was chosen to provide an endogenous 'physiological' stimulus to pancreatic secretion. After an overnight fast a Dreiling double-lumen tube was passed into the duodenum under radiographic control, and basal duodenal juice was collected for one hour while the stomach was continuously aspirated. The test meal was then instilled into the stomach via the gastric lumen, and duodenal juice was continuously collected over 15 minute periods for the next two hours. Samples of duodenal juice were stored at $5^{\circ} \mathrm{C}$ for subsequent measurement of the concentration of $\operatorname{trypsin}^{23}$ and amylase (Phadebas method). The volume and $\mathrm{pH}$ of the juice were also recorded. During the three-hour period of study serum samples were obtained for radioimmunoassy of cholecystokinin $^{24}$ and gastrin. ${ }^{25}$ Gastric acid secretion was measured separately, before and five to seven days after operation; basal acid output was determined, together with the peak acid output to intramuscular pentagastrin $\left(6 \mu \mathrm{g} / \mathrm{kg}: \mathrm{PAO}_{\mathrm{Pg}}\right)$ and intravenous insulin $\left(0.2 \mathrm{IU} / \mathrm{kg}: \mathrm{PAO}_{\mathrm{I}}\right)$. For the postoperative test a larger dose of pentagastrin $(10 \mu \mathrm{g} / \mathrm{kg})$ was used. PAO $_{\mathrm{I}}$ was calculated by subtracting basal acid output from the value derived by doubling the two highest consecutive 15-minute outputs after insulin. PAO $_{\mathrm{Pg}}$ was calculated by trebling the sum of the two highest consecutive

‡ Fifteen grams of casilan, $18 \mathrm{~g}$ corn oil, $40 \mathrm{~g}$ glucose made up to $250 \mathrm{ml}$ with water. 
10-minute outputs after pentagastrin. Completeness of vagotomy was assessed using Hollander's criteria. ${ }^{26}$

Results are expressed as means ( \pm SEM). Statistical significance was assessed by Student's $t$ test for paired data or the Wilcoxon matched-pairs signed-rank test, as appropriate. Integrated values were calculated as previously described ${ }^{27}$ to determine the contribution of altered basal levels to the difference observed in stimulated responses.

\section{Results}

\section{PANCREATIC EXOCRINE FUNCTION \\ Trypsin (Fig. 1)}

The mean preoperative basal trypsin concentration was $4.9 \mathrm{IU} / 1$. This level increased fourfold during the first hour after the Lundh meal and threefold during the second hour. Operation did not significantly affect either the basal or the stimulated concentration, although the trypsin concentration was reduced during the first hour after the food stimulus $(p=0 \cdot 1)$. Total three-hour output and integrated trypsin values were unchanged postoperatively.

\section{Amylase (Fig. 2)}

The Lundh meal failed to produce a significant increase in amylase concentration in the duodenal aspirate either before or after vagotomy. Postoperative amylase concentrations were consistently higher than preoperative values at basal, first, and second hour, but the differences were only significant

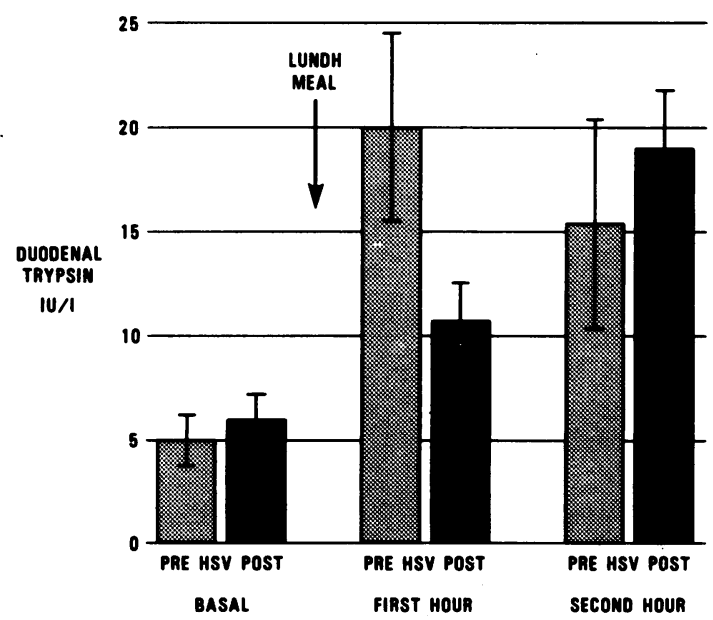

Fig. 1 Duodenal trypsin levels in nine fasting duodenal ulcer patients and for two hours after a Lundh test meal, before and after highly selective vagotomy.

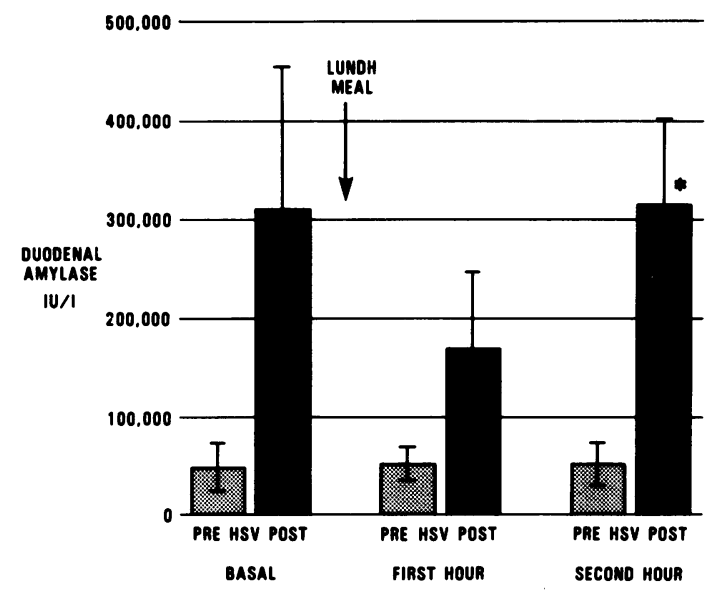

Fig. 2 Duodenal amylase levels in seven fasting duodenal ulcer patients and for two hours after a Lundh test meal, before and after highly selective vagotomy. *Significant difference $(p<0.05)$

during the second hour. When the entire three-hour output was considered, however, amylase concentration was found to be significantly greater after than before highly selective vagotomy $(p<0 \cdot 002)$. Integrated amylase values were not significantly different postoperatively, indicating the change to be in basal levels.

\section{HORMONE ASSAYS}

Cholecystokinin (Fig. 3 and 4)

Both before and after operation the Lundh meal stimulated the secretion of cholecystokinin: preoperative basal levels $(420 \mathrm{pg} / \mathrm{ml})$ were increased threefold 10 minutes after the meal (Fig. 3), while the much greater postoperative basal levels (1987 $\mathrm{pg} / \mathrm{ml}$ ) were further increased to $4282 \mathrm{pg} / \mathrm{ml}$. Integrated cholecystokinin values (Fig. 4) showed that these changes reflected a true increase in release after highly selective vagotomy, from $38 \times$ $10^{3} \mathrm{pg}-\mathrm{min} / \mathrm{ml}$ to $177 \times 10^{3} \mathrm{pg}-\mathrm{min} / \mathrm{ml}$.

\section{Gastrin (Fig. 5)}

Levels were increased after the test meal in both the pre- and postoperative studies. Before vagotomy mean basal gastrin concentration was $52 \mathrm{pg} / \mathrm{ml}$, reaching a plateau at nearly twice this value 10 minutes after food. After vagotomy basal levels were much higher $(210 \mathrm{pg} / \mathrm{ml})$, and stimulated levels remained higher than preoperative values at every time period $(p<0.05)$. The integrated gastrin response to the test meal after highly selective vagotomy, however, did not differ significantly from the preoperative values $(3550 \mathrm{pg}-\mathrm{min} / \mathrm{ml})$. 


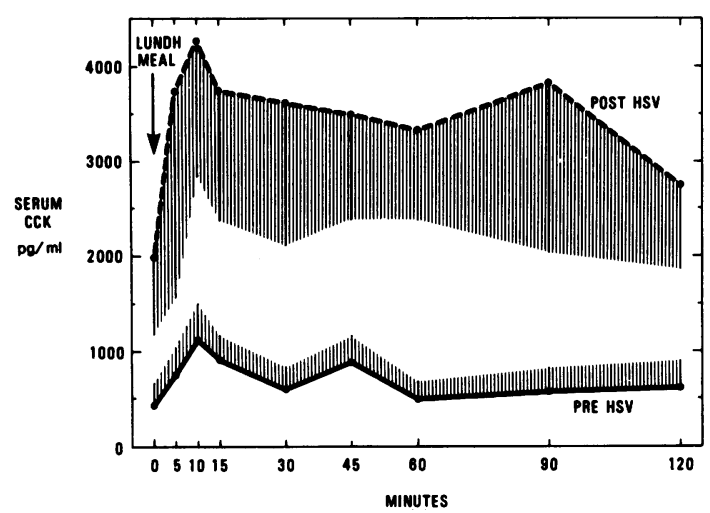

Fig. 3 Serum cholecystokinin levels after a Lundh test meal before and after highly selective vagotomy in nine duodenal ulcer patients. All measurements were significantly higher postoperatively $(p<0.01)$. Crosshatching: standard errors of the mean.

GASTRIC ACID SECRETION (Fig. 6)

Highly selective vagotomy reduced basal acid output by $57 \%, \mathrm{PAO}_{\mathrm{Pg}}$ by $40 \%$ and $\mathrm{PAO}_{\mathrm{I}}$ by $95 \%$. According to Hollander's criteria no patient had an 'early positive' rise, but two patients had 'late positive' responses.

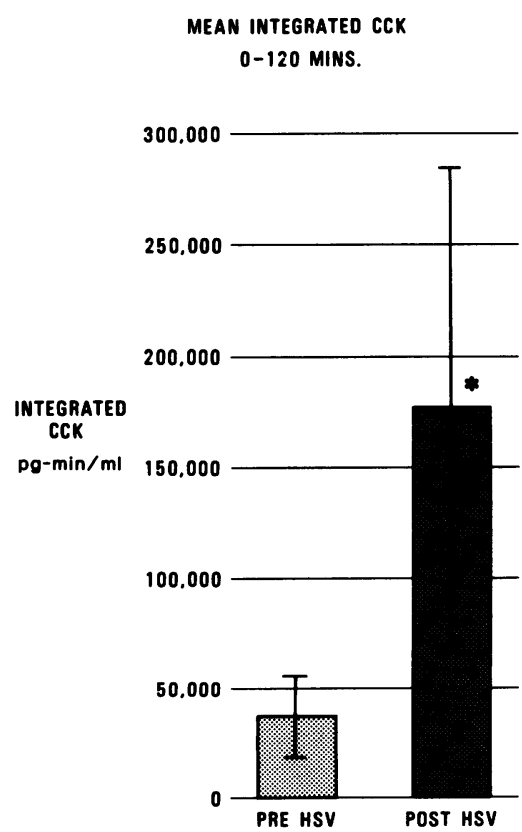

Fig. 4 Mean integrated cholecystokinin levels (0-120 minutes) calculated before and after highly selective vagotomy. *Significant difference $(p<0 \cdot 01)$.

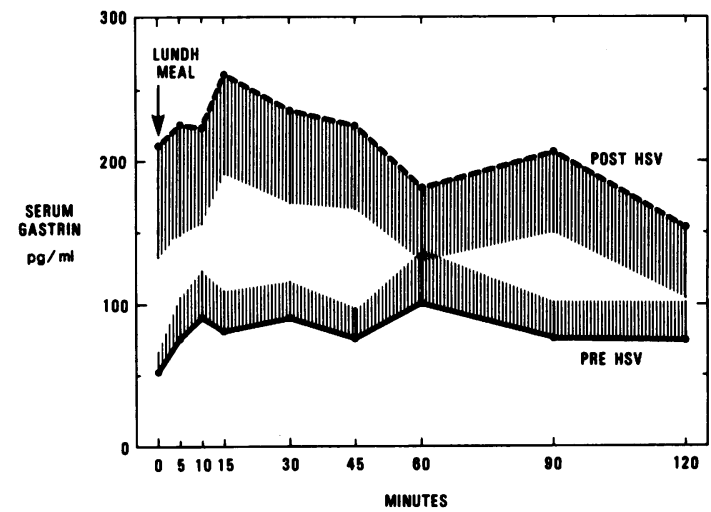

Fig. 5 Serum gastrin levels after a Lundh test meal before and after highly selective vagotomy. All measurements were significantly higher postoperatively $(p<0.05)$.

Crosshatching represents standard errors of the mean.

\section{DUODENAL VOLUME AND $\mathrm{pH}$}

After highly selective vagotomy the volume of duodenal juice tended to be lower throughout the test, but differences only reached statistical significance during the second hour, when the volume fell from $138 \mathrm{ml}$ to $68 \mathrm{ml}(\mathrm{p}<0.05)$.

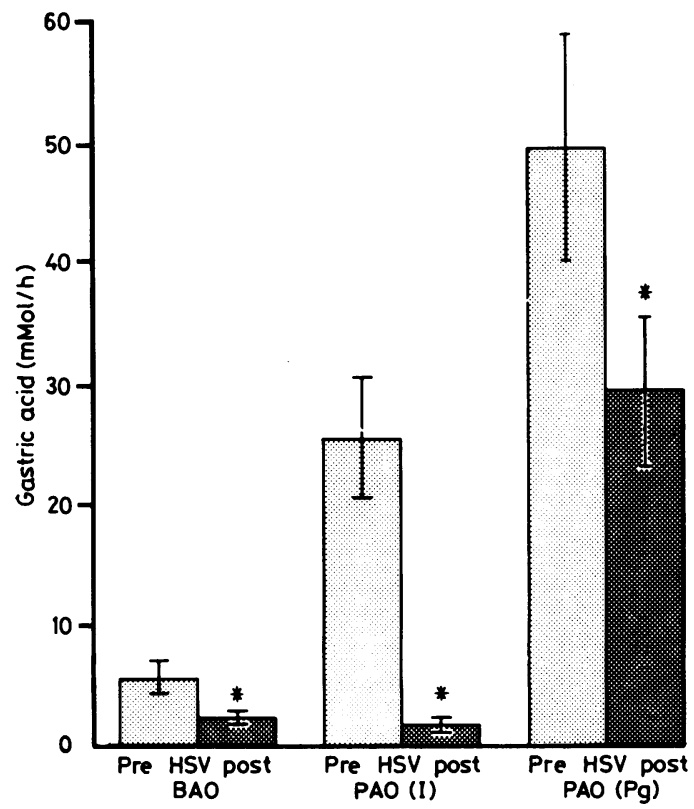

Fig. 6 Gastric acid secretion shown before and after highly selective vagotomy at basal (BAO) and after insulin and pentagastrin stimulation $\left(P A O_{I}\right.$ and $\left.P A O_{P g}\right)$. $P A O_{I}$ levels have had basal acid output subtracted. ${ }^{*}$ Significant differences $(p<0 \cdot 01)$. 
Duodenal $\mathrm{pH}$ was not affected by highly selective vagotomy.

\section{Discussion}

The reductions in basal and stimulated gastric acid secretion indicated that most of the vagotomies had been adequate. Although the endogenous stimulus chosen (a standard Lundh meal) was able to produce a marked increase in duodenal trypsin levels, the concentration of trypsin in the duodenal collections was unaltered by highly selective vagotomy. Our findings are consistent with reports showing that truncal, but not highly selective, vagotomy reduces enzyme output from the pancreas after insulin stimulation, ${ }^{15} 29$ and that virtual abolition of gastric acid output by the $\mathrm{H}_{2}$-receptor antagonist ranitidine does not affect pancreatic enzyme secretion. ${ }^{30}$

The hypotheses advanced to explain impaired pancreatic exocrine function after truncal vagotomy have implicated gastric emptying, which is particularly affected by concomitant pyloroplasty or gastrojejunostomy. ${ }^{14}{ }^{19}$ Highly selective vagotomy, by contrast, has been shown to alter emptying minimally and then only after a fluid test meal. ${ }^{15} 1921$ In the present study the volume of duodenal juice tended to be lower after highly selective vagotomy, though significant differences occurred only during the second hour after the test meal, when trypsin content was unchanged.

Duodenal amylase levels were increased throughout after highly selective vagotomy, but, as there was no amylase response to the Lundh test meal, the reason remains obscure. Increased amylase levels have previously been demonstrated after truncal vagotomy but not after selective vagotomy. ${ }^{31}$ Possible mechanisms for this effect of truncal vagotomy include altered duodenal emptying, ${ }^{31}$ denervation hypersensitivity or loss of vagal inhibition of the pancreas, ${ }^{911} 32$ and changes in cholecystokinin realease. ${ }^{33-35}$ None of these explanations, however, seems directly applicable to the present finding that highly selective vagotomy increases duodenal amylase content. It is conceivable, though unlikely, that, in the present study, contamination by salivary amylase may have affected the results, despite attempts to keep the stomach empty throughout the test period.

Although the cholecystokinin assay probably indicates relative rather than absolute values, in the presence of unchanged trypsin output the increases in serum cholecystokinin and gastrin after highly selective vagotomy suggest a reduction in pancreatic sensitivity. Analysis of the integrated hormone response has shown a true increase in cholecy- stokinin release after highly selective vagotomy. By contrast, raised gastrin levels were only a reflection of the increase in basal levels of gastrin, an established effect of truncal vagotomy. ${ }^{36-38}$ Intragastric titration studies with control of luminal $\mathrm{pH}$ have shown that this post-vagotomy hypergastrinaemia cannot be explained entirely by loss of inhibition by endogenous $\mathrm{HCl}$ when acid secretion is reduced. ${ }^{39}$ The increased cholecystokinin release noted in this study might be needed to achieve the same enzyme output from the pancreas, if reduced acid secretion after highly selective vagotomy diminished pancreatic sensitivity. Yet Berstad and associates (1976) have demonstrated what they believe to be an increased pancreatic sensitivity to secretion after highly selective vagotomy and suggest decreased acid output as the possible aetiological factor. ${ }^{40}$ As gastrin acts as a tropic hormone to the pancreas, at least in the rat, ${ }^{41-43}$ some indirect increase in exocrine function might be expected to balance the effects of any pancreatic denervation and reduced gastric acidity.

We conclude that highly selective vagotomy produces a satisfactory reduction in acid secretion in duodenal ulcer disease without appreciably altering pancreatic exocrine function.

We thank Dr Richard Harvey for permission to use his cholecystokinin assay and Mrs R Pratt of the University Department of Medicine, Bristol Royal Infirmary, who performed the Lundh test meals.

\section{References}

1 Cox AG, Bond MR. Bowel habit after vagotomy and gastrojejunostomy. Br Med J 1964; 1: 460-5.

2 Logan H. Steatorrhoea and diarrhoea after vagotomy: a comparison of drainage procedures. Gut 1964; 5: 188-91.

3 Kennedy TL, Connell AM. Selective or truncal vagotomy? Lancet 1970; 1: 675.

4 Wastell C, Ellis H. Faecal fat excretion and stool colour after vagotomy and pyloroplasty. $\mathrm{Br} \mathrm{Med} J$ 1966; 1: 1194-7.

5 Humphrey CS, Johnston D, Walker BE, Pulvertaft $\mathrm{CN}$, Goligher JC. Incidence of dumping after truncal and selective vagotomy with pyloroplasty and highly selective vagotomy without drainage procedure. $\mathrm{Br}$ Med J 1972; 3: 785-8.

6 Johnston D, Humphrey CS, Walker BE, Pulvertaft $\mathrm{CN}$, Goligher JC. Vagotomy without diarrhoea. $\mathrm{Br}$ Med J 1972; 3: 788-90.

7 Parkin GJS, Smith RB, Johnston D. Gall bladder volume and contractility after truncal, selective and highly selective (parietal cell) vagotomy in man. Ann Surg 1973; 178: 581-6.

8 Edwards JP, Lyndon PJ, Smith RB, Johnston D. Faecal fat excretion after truncal, selective and highly 
selective vagotomy for duodenal ulcer. Gut 1974; 15: 521-5.

9 Tinker J, Cox AG. Gallbladder function after vagotomy. Br J Surg 1969; 56: 779-82.

10 Wormsley KG. The effect of vagotomy on the human pancreatic response to direct and indirect stimulation. Scand J Gastroenterol 1972; 7: 85-91.

11 Thambugala RL, Baron JH. Pancreatic secretion after selective and truncal vagotomy in the dog. Br J Surg 1971; 58: 839-44.

12 Malagelada JR, Go VLW, Summerskill WHJ. Altered pancreatic and biliary function after vagotomy and pyloroplasty. Gastroenterology 1974; 66: 22-7.

13 MacGregor IL, Parent J, Meyer JH. Gastric emptying of liquid meals and pancreatic and biliary secretion after subtotal gastrectomy or truncal vagotomy and pyloroplasty in man. Gastroenterology 1977; 72: 195205.

14 McKelvey STD. Gastric incontinence and postvagotomy diarrhoea. Br J Surg 1970; 57: 741-7.

15 Lavigne ME, Wiley ZD, Martin P, Way LW, Meyer JH, Sleisenger MH, MacGregor IL. Gastric, pancreatic and biliary secretion and the rate of gastric emptying following parietal cell vagotomy. Am J Surg 1979; 138: 644-51.

16 Solomon TE, Grossman MI. Cholecystokinin and secretin release are not affected by vagotomy or atropine. Gastroenterology 1977; 72: A-111/1134.

$17 \mathrm{De}$ Miguel J. Diarrea tras diversas formas de vagotomia con y sin drenaje complementario. Rev Esp Enferm Apar Dig 1972; 38: 595-600.

18 Johnston D, Axon ATR. Highly selective vagotomy for duodenal ulcer: the clinical results after 10 years. $\mathrm{Br} \mathrm{J}$ Surg 1979; 66: 874.

19 Clarke RJ, Alexander-Williams J. The effect of preserving antral innervation and of a pyloroplasty on gastric emptying after vagotomy in man. Gut 1973; 14: 300-7.

20 Brandsborg $\mathrm{O}$, Brandsborg $\mathrm{M}$, Løvgreen NA, Mikkelsen K, Møller B, Rokkjaer M, Amdrup E. Influence of parietal cell vagotomy and selective gastric vagotomy on gastric emptying rate and serum gastrin concentration. Gastroenterology 1977; 72: 212-4.

21 Binswanger RO, Aeberhard P, Walther M, Vock P. Effect of pyloroplasty on gastric emptying: long term results as obtained with a labelled test meal 14-43 months after operation. Br J Surg 1978; 65: 27-9.

22 Johnston D, Wilkinson AR. Highly selective vagotomy without a drainage procedure in the treatment of duodenal ulcer. Br J Surg 1970; 57: 289-96.

23 Wiggins HS. Simple method of estimating trypsin. Gut 1967; 8: 415-6.

24 Harvey RF, Oliver JM. Hormonal content and effects on gallbladder of commercial preparations of cholecystokinin-pancreozymin. Horm Metab Res 1981; 13: 446-50.

25 Spence RW, Celestin LR, McCormick DA, Owens CJ, Oliver JM. Effect of long term treatment with cimetidine on gastric acid secretion and gastrin response in man. In: W Creuzfeldt, ed. Cimetidine: Proceedings of International Symposium on Histamine $\mathrm{H}_{2}$-receptor Antagonists. Gottingen 1977. Amsterdam:
Excerpta Medica, 1978: 116-34.

26 Hollander $F$. The insulin test for the presence of intact nerve fibres after vagal operations for peptic ulcer. Gastroenterology 1946; 7: 607-14.

27 Thompson JC, Reeder DD, Bunchman HH, Becker HD, Brandt ENJr. Effect of secretion on circulating gastrin. Ann Surg 1972; 176: 384-93.

28 Greenall MJ, Lyndon PJ, Goligher JC, Johnston D. Long term effect of highly selective vagatomy on basal and maximal acid output in man. Gastroenterology 1975; 68: 1421-5.

29 Smith RB, Edwards JP, Johnston D. Effect of vagotomy on exocrine pancreatic and biliary secretion in man. Am J Surg 1981; 141: 40-7.

30 Konturek SJ, Obtulowicz W, Kwiecien N, Sito E, Oleksy J, Miszczuk-Jamska B. Effect of ranitidine, a new $\mathrm{H}_{2}$-antagonist, on gastric and pancreatic secretion in duodenal ulcer patients. Dig Dis 1980; 25: 737-43.

31 Kramhöft J, Balslev I, Lindahl F, Backer OG. Vagotomy and the external function of the pancreas. Scand J Gastroenterol 1974; 9: 309-11.

32 Davenport HW. Physiology of the digestive tract. Pancreatic secretion. Chicago: Year Book Medical Publishers Incorporated, 1966: 136.

33 Gamble WS. Impaired pancreozymin secretion after vagotomy and pyloroplasty. J Lab Clin Med 1970; 76: 871.

34 Moreland HJ, Johnson LR. Effect of vagotomy on pancreatic secretion stimulated by endogenous and exogenous secretin. Gastroenterology 1971; 60: 425-31.

35 Grossman MI. Gastrointestinal hormones: some thoughts about clinical applications. Scand $J$ Gastroenterol 1972; 7: 97-104.

36 Hansky J, Korman MG. Immunoassay studies in peptic ulcer. In: Sircus W, ed. Clinics in gastroenterology. Vol 2. New York and London: Saunders, 1973: 275-91.

37 Thompson JC. The effect of vagotomy on circulating gastrin. In: Holle F, Andersson S, eds. Vagotomy, latest advances, New York: Springer-Verlag, 1974: 59-64.

38 Thompson JC, Fender HR, Watson LC, Villar HV. The effects on gastrin and gastric secretion of five current operations for duodenal ulcer. Ann Surg 1976; 183: 599-607.

39 Thompson JC, Lowder WS, Peurifoy JT, Swierczek JS, Rayford PL. Effect of selective proximal vagotomy and truncal vagotomy on gastric acid and serum gastrin responses to a meal in duodenal ulcer patients. Ann Surg 1978; 188: 431-7.

40 Berstad A, Roland M, Peterson H, Liavåg I. Altered pancreatic function after proximal gastric vagotomy in man. Gastroenterology 1976; 71: 958-60.

41 Mayston PD, Barrowman JA. Influence of chronic administration of pentagastrin on the pancreas in hypophysectomised rats. Gastroenterology 1973; 64: 391-9.

42 Debinski AB, Johnson LR. Growth of pancreas and gastointestinal mucosa in antrectomized and gastrintreated rats. Endocrinology 1979; 105: 769-73.

43 Koizumi K, Okubo M, Inove S, Masuda H. Trophic effect of tetragastrin on the stomach, duodenum and pancreas in rats. Tohoku J Exp Med 1979; 129: 17-24. 